\title{
Turisztikai karrierperspektívák vizsgálata a Covid19- járvány árnyékában - Turizmus-menedzsment mesterszakos hallgatók percepciói
}

\section{Analysing the tourism career perspectives under the shadow of Covid19 - the perceptions of Tourism and Management MSc students}

\author{
Szerzők: Formádi Katalin ${ }^{1}$ - Gyurácz-Németh Petra²
}

\begin{abstract}
A kutatás célja a koronavírus-járvány által erősen sújtott turizmus szektor utánpótlását jelentő Turizmus-menedzsment mesterszakos hallgatók karrierelképzeléseinek feltérképezése. További cél a múltbeli turisztikai tapasztalat és a jövőbeli lehetőségek vizsgálata, valamint az alsóbb és felsőbb éves hallgatók észlelésében való különbségek feltárása, különösen a munkaorientáció és a turisztikai munkafeltételek tekintetében. A fókuszcsoportos interjú módszerét alkalmaztuk, ahol három csoportban, guide segítségével térképeztük fel a témát. A turisztikai munkavégzéssel kapcsolatban az elsőéves mesterszakos hallgatók véleménye bizakodóbb volt, mint a végzősöké. A megnevezett szakmai motiváló tényezők közül legtöbben az anyagi és a szakmai megbecsülést tartják fontosnak, míg a munkavégzésben a szakmai kihívásokat, a változatos feladatokat és a megfelelő munkaidőbeosztást. A válaszokból az látható, hogy a hallgatók számára kiemelt jelentőséggel bír a pozitív szakmai orientáció, a szakma szeretete. Az eredmények fényében megállapítható, hogy az alsóbb éves hallgatók még szinte kivétel nélkül a turizmusban képzelik el a jövőjüket, habár őket is megrázta a koronavírus-járvány okozta válság. A végzős hallgatók esetében viszont már sokkal több kétség merül fel a turisztikai munkával kapcsolatban.
\end{abstract}

\begin{abstract}
The aim of the research is to investigate the career perspectives of the Tourism and Management MSc students in the tourism sector, which was impacted by the Covid19 pandemic. Additionally, our goal was to analyse the differences between the perceptions of the first year and senior MSc students, concentrating on work orientation and working conditions - and to gain information about their past professional experience as well as their future plans. Three focus group interviews were held, concentrating on the research goals. First year Master students' opinions were more positive than those of senior Master students towards tourism jobs. The most important motivational factors are financial rewards and professional appreciation as well as the challenges, variable tasks and flexible schedule. Students seem to be fond of the tourism profession, they have a positive inclination to tourism jobs. The results also show that first year MSc students are more dedicated to tourism jobs, although they are also concerned about the effect of the pandemic, whilst senior MSc students are doubtful about working in tourism.
\end{abstract}

Kulcsszavak: Covid19, munkaorientáció, karrier lehetőségek.

Keywords: Covid19, work orientation, career perspectives.

\section{Bevezetés}

A Covid19-járvány erôsen megrázta, sőt megtörte a turizmust 2020 első negyedévében, annak elle-

egyetemi docens, Pannon Egyetem, formadi.katalin@gtk.uni-pannon.hu

egyetemi docens, Pannon Egyetem, nemeth.petra@gtk.uni-pannon.hu 
nére, hogy a jelek már 2019 végén mutatkoztak. A globális pandémia egyértelmúen a turizmus szektort érintette a legjobban (COLLINS et al. 2021), elsősorban annak sebezhetósége miatt (SIGALA 2020, UĞUR-AKBIYIK 2020), ami a korábbi gazdasági válságok - például a 2008-as recesszió - során is megfigyelhetó volt (ZHANG et al. 2020). A turizmus szektorra már a járvány előtt is a munkaeróhiány volt jellemzó, melyet vagy nem ismertek fel, vagy nem kezeltek hatásosan sem az ágazati szereplók, sem a szabályozó szervezetek (JOPPE 2012, TURIZMUS ONLINE 2019). A 2019-es, kifejezetten jó eredményeket produkáló évben a szálloda szektorból 10.000 fó hiányzott (TURIZMUS. COM 2021a).

A 2008-2009-es gazdasági világválság után a turizmus újra felfutásnak indult. A kereslet nagymértékben nőtt, miközben a munkaerő mennyisége nem tudott lépést tartani a turizmus gazdasági jelentőségével, így a munkaerőhiány és -fluktuáció egyre nagyobb problémává vált (JOPPE 2012). A mostani, precedens nélküli válság hatására láthatóan sok szakember hagyta el a turizmus szektort. A Magyar Szállodák és Éttermek Szövetségének alelnöke szerint a pályaelhagyók aránya jelenleg 25\%-30\%, ami egy újabb hullám esetén jelentősen növekedhet (TURIZMUS.COM 2021b). Azonban a koronavírus-járvány következtében megváltozott utazási szokások éppen a képzettebb, felkészültebb és nagyobb számú személyzet alkalmazását tennék szükségessé ahhoz, hogy a biztonság iránti igényt jobban ki tudják elégíteni a szolgáltatók (FELKAI 2021).

Az ország turisztikai jellemzői a munkaerőhiányra is hatással vannak, illetve bizonyos területeken átrendeződés várható a következô idôszakban. 2017-ben az országba érkező külföldi vendégkör elsődleges célpontja, ezáltal a turizmus szempontjából legfontosabb település, Budapest volt (a külföldi vendégéjszakák 59,2\%-a itt realizálódott, MTÜ 2017a), a második Hévíz, a harmadik pedig Hajdúszoboszló (MTÜ 2017b). A járvány hatására ezeknek a városoknak, illetve térségeknek egyértelmúen újra kellett pozícionálniuk magukat, ami a vidéki településeknek jobban sikerült, mivel a külföldiek mellett a magyar vendégek számára is vonzó célpontok voltak, amit a járvány időszakában megerősítettek. A budapesti szállodák esetleges jövóbeni újranyitása esetében épp a munkaerőhiány lesz a hátráltató tényező (TURIZMUS.COM 2021a).

A munkaerőhiány mérséklését vagy további erôsödését (amennyiben a hallgatók más pályát választanak) is eredményezheti a turizmust tanuló diákok belépése a munkaerôpiacra. Ezen diákok turizmus szakmával/karrierjével kapcsolatos atti- túdje tehát erősen befolyásolhatja a munkaeróhiány alakulását. Jelen kutatás a Turizmus-menedzsment mesterszakos hallgatók kezdeti karrier perspektíváit vizsgálja a munkavállalási hajlandóságra, illetve a kritériumokra fókuszálva, amelyek ismeretében a turisztikai szolgáltatók a pályán tudnák tartani a frissen végzett és jól képzett munkaerőt.

\section{Szakirodalmi áttekintés}

A következókben szakirodalmi forrásokra alapozva áttekintjük azokat a belső és külső tényezóket, amelyek a kutatási témához kapcsolódóan megalapozták a kutatás módszertanát. A belső tényezők közül a munkaorientáció és a turisztikai munkavégzéssel kapcsolatos elvárások, motivációk elméletét tekintjük át, amelyek befolyásolhatják a turisztikai munkavállalási hajlandóságot. A külső tényezők közül elsősorban a Covid19-világjárványnak mely a 2020-as év eleje óta egyértelmúen negatívan hat globálisan az egész szektorra- a turisztikai pályaelhagyásra gyakorolt hatásait elemezzük.

\subsection{BELSŐ TÉNYEZŐK VIZSGÁLATA}

\subsubsection{Munkaorientáció és elvárások}

A munkaorientáció fogalma elvárásokból és motivációkból áll, melyeken keresztül az emberek a munkaszituációjukhoz kapcsolódnak (REED 1997, LIN et al. 2020). A kutatás szempontjából a fogalom használatának célja, hogy megértsük a munkatapasztalattal kapcsolatos változásokat, és fényt derítsünk a szektor vonzerejére.

A munkatapasztalat egy kulcsfogalom a munka- és foglalkozás pszichológiában és szociológiában. A fogalom két fó aspektusból áll: egyrészt a cél vagy az eredmény, mely orientálja a dolgozók szándékát, motivációit, cselekvéseit; másrészt a szociális beállítottság, a környezeti tényezô, mely lehetőségeket teremt, illetve arra készteti a dolgozót, hogy elérje ezeket a célokat. Ez a két komponens befolyásolja a munkával való elégedettséget és a karrierdöntéseket: mit akarnak a dolgozók a munkától, és mit tud számukra nyújtani a munka (LOCKE 1984, REED 1997, LIN et al. 2020). Több kutató (JUNG-YOON 2016, AKGUNDUZ et al. 2018, LIN et al. 2020) tett kísérletet a munkaorientáció fogalmi keretének meghatározására, de a fogalom összetettsége miatt nem született egységes megközelítés. A munkához való viszonyt számos belsô pszichológiai tényező (pl. generációs jellemzők, motiváció, elköteleződés) és külső környezeti tényező (kulturális környezet, gazdasági lehetóségek stb.) együttesen befolyásolja. Néhány, a munkaorientációra vonatkozó megközelítés meghatározza 
a munkavállalók szektorral kapcsolatos hozzáállását, a munkával kapcsolatos elkötelezettségét és az orientáció típusát (GOLDTHORPE et al. 1968, HARPAZ et al. 2002, LIPS-WIERSMA-WRIGHT 2012, ARNOUX-NICHOLAS et al. 2017).

Korábbi kutatási eredményre építve a turizmusban alkalmazott munkaorientációs dimenziók lehetséges típusai az alábbiak (FORMÁDI 2008):

- megélhetési eszközként kezelés - instrumentális orientáció (az élethez szükséges bevétel elérése a munkán keresztül);

- vállalkozói orientáció (tudás megszerzése saját vállalkozás indításához);

- pozitív hozzáállás (a munka szeretete, annak értéke, a munkafeltételek, a presztízs stb. miatt);

- túlélő orientáció (a legkevésbé rossz opció a munka, meneküló út).

A kutatások általában a különféle motivációs tényezőket is feltérképezik a munka, illetve szakma megválasztásával kapcsolatban. A szakma megválasztása, valamint az azzal kapcsolatos orientáció elemzésén keresztül feltárjuk, hogy a turizmusban dolgozók hogyan kezdenek el, illetve kezdtek el a turizmusban munkát vállalni, továbbá, hogy milyenek az egyéni orientációk a turizmus különbözó területein. A kezdeti hatások befolyással vannak a későbbi turisztikai karrierdöntésekre, karrierútvonalakra, amelyek nagy mértékben függenek a strukturális tényezőktól és a környezeti hatásoktól (ld. Covid hatás), melyekre a következó alpontban térünk ki részletesen.

Nagyon fontos, hogy a karriert ne úgy definiáljuk, mint a „társadalmi pozíciók sorozata, melyet az ember az élete során betölt" (WATSON 1995:127), hanem egy érme két oldalaként, objektív és szubjektív karrierként határozzuk meg (FORMÁDI 2008, FORMÁDI-RAFFAI 2009). Az objektív karrier ",az egyén különböző szerepeinek alakulási folyamata külsó szemléló szemszögéből" (GUERRIER 1987:122). Ide tartoznak a mérhetó ösztönzők (fizetés, rang, hatalom, befolyás stb.) Ellenben a szubjektív karrier „az egyén általi értékítélet az életében betöltött társadalmi pozíciókkal kapcsolatban" (GUERRIER 1987:123, WATSON 1995:127), például nem mérhetó ösztönzők, mint a rugalmasság, autonómia, változatosság. A karrierlehetóségeket, döntéseket nem utolsósorban az is befolyásolja, hogyan érzi magát a munkavállaló az adott szektorban, munkahelyen, illetve munkakörben, mennyire elkötelezett aziránt (LIN et al. 2018).

A munkabeli tapasztalat fogalma megmutatja, hogy a turisztikai munka elég vonzó-e egy lineáris karrierút (objektíven vagy szubjektíven nézve) folytatásához, hogy a Covid19 miatti rövid szünet után gyors visszatérés várható vagy esetleg egy teljesen új karrierút kezdődik.

\subsection{KÜLSŐ TÉNYEZŐK}

\subsubsection{A Covid19 következményei a turizmusban}

A turizmus teljesítménye jelentôsen hozzájárult mind a globális, mind a magyar gazdaság eredményéhez az elmúlt években. A 2019-es adatok egyértelmúen bizonyítják a turizmus folyamatos növekedését, mivel a nemzetközi turistaérkezések (legalább egy éjszakát a területen töltők) száma világszerte elérte az 1,5 milliárdot (UNWTO 2020). Magyarországon a 2018-as év nevezhető rekordnak, amikor a magyar GDP-hez való közvetlen hozzájárulás 6,8\%, a közvetett 10,7\% volt (MTÜ 2019), és 185.963 ember dolgozott a szektorban, akik közül a legtöbben szállás és vendéglátó szolgáltatással foglalkoztak (OECD 2020). Az előrejelzések globális szinten 3\%-4\%-os növekedést jósoltak 2020-ra (UNWTO 2020), amit a Covid19 egyértelmúen aláásott, lévén a nemzetközi turistaérkezések a várt növekedés helyett $78 \%$-kal csökkentek (1,2 trillió dollár veszteséget generálva), ami a történelem legnagyobb visszaesése (SIGALA 2020, FOTIADIS et al. 2021). A fenti adatok jól szemléltetik a turizmus jelentőségét a magyar gazdaságban is. Ez a hozzáadott érték csökkent és semmisült meg 2020-ban a globális járvány hatására (KSH 2020). A munkaerő fluktuációja mindig problémákat okozott a szektor résztvevői számára (RASHEED et al. 2020, FILIMONAU et al. 2020, AIGBEDO 2021), de az előző évben a szállodák, éttermek, utazási irodák, fürdők, múzeumok és egyéb attrakciók bezártak, sokuknak el is kellett bocsátania a személyzetet, vagy fizetés nélküli szabadságra küldeni óket. Ezek a munkavállalók nemcsak a céget hagyták el, hanem sok esetben az egész szektort maguk mögött hagyták, hogy más karrierutat építsenek. A megüresedett álláshelyek betöltésére általában megfelelőek lennének a végzős egyetemi hallgatók, amennyiben tanulmányaik végeztével a turisztikai pályán maradnak.

A turizmus szektorban maradást megnehezítik a 2020-as események, a Covid19-járvány és annak következményei. A diákok motivációinak és elvárásainak feltérképezése kifejezetten kutatott területnek számít a nemzetközi szakirodalomban (GETZ 1994, AIREY-FRONTISTIS 1997, RICHARDSON 2009, RICHARDSON-THOMAS 2012, KIM et al. 2016, FARMAKI 2018, RAMAKRISHNANAMACAVEIU 2019). Azonban a világjárvány és a turizmus kapitulációja teljes mértékben megváltoztatta mind a kilátásokat, mind az elvárásokat. Jelenleg a turizmus képzésben résztvevők és a vég- 
zős, turizmust tanuló hallgatók jelentik a szakma jövőjét, az ő karrierútjuk kulcskérdés a szektor múködése szempontjából.

SIGALA (2020) meghatározta a Covid19 után, illetve következtében átalakuló kutatási irányokat, melyek közt szerepelteti az alkalmazottak elkötelezettségének szerepét, illetve az átképzésük vagy újraképzésük szükségességét. Nem említi azonban a pályaelhagyásból adódó problémákat, tehát a munkaerőhiány megjelenését - több országban erôsödését - a turisztikai szektorban.

\section{Kutatásmódszertan}

Kutatásunk során azt vizsgáltuk, hogy a mesterszakos képzésben tanuló és a mesterképzésen végzős hallgatók, akik épp karrierjük elsô lépéseinél tartanak, milyen korábbi munkatapasztalatokkal és benyomásokkal rendelkeznek, milyen munkafeltételeket tartanak fontosnak és hogyan látják munkalehetőségeiket a diplomaszerzést követően. Kutatási kérdéseink a belső és külső tényezők vizsgálatára irányultak:

- Milyen tényezók játszanak szerepet a turizmusban tanuló hallgatók munkaorientációja szempontjából? Milyen elvárásaik vannak a turisztikai munkavégzéssel (munkafeltételekkel) kapcsolatban?

- Milyen hatással van a Covid19-járvány a turisztikai karrier döntéseikre és hogyan látják a turizmus szakma jövőjét?

Az okok mélyebb elemzésére fókuszcsoportos interjúkat készítettünk. A fókuszcsoportos interjú (AIREY-FRONTISTIS 1997) elterjedt technika a szükséges kvalitatív adatok összegyújtésére, ami előkészíti a kvantitatív kutatást, megalapozza a később lekérdezendő kérdőívet. A fókuszcsoportos interjú feltáró kutatásra alkalmas módszer, melynek segítségével válaszokat keresünk egy jelenség megértéséhez, megismerjük a résztvevők véleményét, attitúdjét, motivációit, ugyanakkor szem előtt tartva, hogy a kevés számú megkérdezett miatt az eredmények nem általánosíthatóak. A fókuszcsoportos felmérések időtartama 90-110 perc volt, mely során előre kialakított vezérfonal (guide) mentén haladtunk egy moderátor segítségével. A guide nyitott kérdések formájában négy nagy témablokkot ölelt fel:

- a Covid19 következményei a turizmusban és a hallgatók életében,

- hallgatói elvárások a turisztikai munkával kapcsolatban (munkaorientáció, motiváció),

- munkafeltételek és munkatapasztalatok vizsgálata, és

- a turizmus jövőjének megítélése.
A járványügyi korlátozások miatt a fókuszcsoportos interjúk videokonferencia jelleggel online zajlottak.

A fókuszcsoportokba jelenlegi elsőéves és végzős turizmus mesterszakon tanuló hallgatókat vontunk be, akik tudatosan választották a turizmus mesterszakot, valamint már rendelkeznek munkatapasztalatokkal a turizmus különböző területein: szálloda, étterem, utazási iroda, rendezvényszervezés, idegenvezetés, egyéb turisztikai létesítmények. A munkatapasztalatokat és a szakmai motivációkat is feltáró interjúk kvalitatív adatokat szolgáltattak a hallgatók elsố tapasztalatairól, munkaorientációjukban történt változásokról és azon tényezőkről, melyek befolyással lehetnek a vizsgálatban résztvevők karrierdöntéseire a vizsgált időszakban.

A minta összeállítását a teljes sokaság feltérképezésével kezdtük. A kutatásba csak a Pannon Egyetemen, nappali tagozaton tanuló mesterszakos hallgatókat vontuk be. Az elsóévesek esetében ez hét hallgatót jelent, míg a másodévesek esetében 8 fôt. Az alsóbb évesek közül mindenki rendelkezésre állt, a felsőbb évesek esetében a 8 fóből 6 hallgatóval tudtunk fókuszcsoportos interjút készíteni. Az elsősöknél tehát 100\%-os, míg a végzôsöknél $75 \%$-os volt a minta aránya a sokasághoz képest, mely alátámasztja a hallgatók véleményének relevanciáját, ugyanakkor a kis létszámú szakokból kifolyólag felerősíti a kutatás korlátait.

A jelenlegi kutatás eredményei a Pannon Egyetem mesterszakos hallgatóinak véleményét tükrözik, ezért elsősorban esettanulmánynak tekinthető, mely a későbbi kutatási irányok és módszerek megalapozását szolgálja.

\section{Eredmények, kilátások}

\subsection{MUNKAORIENTÁCIÓ ÉS ELVÁRÁSOK A MESTERSZAKOS HALLGATÓK ESETÉBEN}

Ahogy az 1. táblázatból látható, a munka megítélését nagy mértékben meghatározzák a korábbi munkatapasztalatok, az azzal kapcsolatos pozitív és negatív élmények, az elsô benyomások. A munkához kötődő értékek és attitûdök gyökere a tágabb társadalmi környezetben keresendő. Megfigyelhető, hogy a család és a tágabb környezet erősen meghatározó a szakma kiválasztásában, megítélésben, az úgynevezett szakmai orientáció szempontjából. Ez harmonizál a szakirodalomban leírtakkal (REED 1997, LOCKE 1984, LIN et al. 2020).

Az interjúalanyokat megkérdeztük arról, hogy milyen elvárásaik vannak a turisztikai munkával kapcsolatban, milyen szakmai tényezôk motiválják óket a turisztikai munkavállalásban. Az elsőéves mesterszakos hallgatók véleménye sokkal pozití- 
vabb volt, mint a végzősöké. A megnevezett szakmai motiváló tényezők közül legtöbben az anyagi és a szakmai megbecsülést tartják fontosnak, míg a munkavégzésben a szakmai kihívásokat, a változatos feladatokat és a megfelelő munkaidő-beosztást. Ugyanakkor az önállóság, a felelősség kevésbé jelent meg motiváló tényezőként, aminek egyik magyarázata, hogy a hallgatók még nem rendelkeznek elegendő munkatapasztalattal, ezért a szabványosított feladatok, a szabályozott napi feladatok könnyebb eligazodást jelentenek nekik.

A megnevezett tényezők között kulturális különbségek rajzolódnak ki (pl. a munkahelyi biztonság, a munkával járó társadalombiztosítás eltérő fontossággal bír) a hazai és a külföldi diákok között, de a minta kis elemszáma miatt nem lehet következtetéseket levonni, ahhoz további vizsgálatok szükségesek. Összegezve, a hallgatók által megnevezett szakmai motiváló tényezők az alábbiak:

- anyagi megbecsülés - tisztességes jövedelem, fizetés,

- szakmai megbecsülés és kihívások - képességekre (nyelvtudásra, szakmai tanult ismeretekre) épülő feladatok, sikerélmény a munkában,

- előmeneteli lehetőség - karrierlehetőség és a képességek fejlesztésének lehetôsége,

- érdekes, változatos munka és sikerélmény a munkában.

Az egyéb ösztönzők, bónuszok, a lakóhely-munkahely távolsága, az önállóság, a rugalmasság, a munkával járó társadalmi státusz, presztízs ennél a korosztálynál nem jelent meg.

A hallgatók szakmai orientációja szempontjából fontosnak tartottuk azt feltárni, hogy miért kezdtek el a turizmusban dolgozni, mi indította el óket, hogy turizmust tanuljanak, és a korábbi munkatapasztalatuk alapján mit ad nekik, hogy a turizmusban dolgozhatnak. A fókuszcsoportos vizsgálatban résztvevő hallgatók szakmai orientációját tekintve két fő irány rajzolódott ki. Egyfelől a családi indíttatás, akár családi vállalkozás, akár családtag munkavállalása a turizmusban. Itt megfigyelhető, hogy az úgynevezett pozitív szemlélet, munkaorientáció a turizmussal kapcsolatban erôteljesebb, mint a vállalkozói munkaorientáció, még azok körében is, akik saját családi vállalkozásban dolgoznak (többen említették a munka szeretetét, mint a nyereséges vállalkozási szemléletet). Másfelől, külső hatásként említendők a (gyakorlati) munka során szerzett utazási élmények, a kalandvágy, az új desztinációk felfedezése, a munkavégzés kellemes munkakörnyezetben és a kedvezőbb utazási lehetôség turisztikai munkavállalás esetén.

Az interjú során elhangzott, hogy komoly befolyásoló szerepe van a családi környezetnek, mind negatív, mind pozitív irányban. Két esetben is elhangzott, hogy családi javaslat ellenére - mely a Covid19-járvány hatására még erősebb lett - választotta a hallgató a turizmus szakot és a turisztikai munkavállalást, ezért a negatív vélemények miatt kiemelten fontos a turizmus szakma jövőjének vizsgálata, a turisztikai munkavállalási kedvnek és a szakma megítélésének javítása. A turizmus szakma vonzereje a munkavállalás mellett a turisztikai oktatási intézmények szempontjából is lényeges.

\subsection{MUNKAFELTÉTELEK AZ ELSÖÉVES ÉS A VÉGZŐS HALLGATÓK ESETÉBEN}

A mesterszakos hallgatók esetében a múltbeli turisztikai tapasztalatokra is kitértünk a fókuszcsoportos interjú során, melyet az elsóévesekre vonatkozóan az 1. táblázatban foglalunk össze, míg a végzősök munkatapasztalatait a 2. táblázatban mutatjuk be.

\section{Elsóéves mesterszakos hallgatók munkatapasztalatainak összegzése}

\begin{tabular}{|c|c|c|c|c|}
\hline Csoporttag & Tapasztalat & Terïlet & Nyár & Jövő \\
\hline$A$ & $1 e ́ v$ & Hotel FO & Folyamatos munka & Turizmus \\
\hline$B$ & Sokév & $\begin{array}{c}\text { FEB (családi kávézó) } \\
\text { 3 hónapos szállodai gyakorlat }\end{array}$ & Megy vissza a szállodába & Turizmus \\
\hline$C$ & $\begin{array}{l}\text { Szakmai } \\
\text { gyakorlat }\end{array}$ & $\begin{array}{l}\text { Hotel (rotációban) } \\
\text { Utazási iroda }\end{array}$ & & Turizmus \\
\hline$D$ & 2 év & Idegenvezetô (attrakciónál) & $\begin{array}{c}\text { Lehetöség szerint magyar munka, saját országban nincs } \\
\text { erre lehetôség jelenleg }\end{array}$ & \\
\hline$E$ & & & Hotel, Budapest & \\
\hline$F$ & & & Étterem, Kína & Turizmus \\
\hline G & Néhány hónap & Idegenvezetô & & \\
\hline
\end{tabular}

Forrás: saját szerkesztés 
Végzős mesterszakos hallgatók munkatapasztalatainak összegzése

\begin{tabular}{|l|c|c|c|c|}
\hline Csoporttag & Tapasztalat & Terület & Nyár & Jövó \\
\hline A & $7 e ́ v$ & $\begin{array}{c}\text { Légitársaság, utazási iroda } \\
\text { marketing }\end{array}$ & $\begin{array}{c}\text { Covid19 miatt nincs } \\
\text { lehetóség }\end{array}$ & Saját vállalkozás \\
\hline B & Kb.8év & Hotel animátor, családi vállalkozás & $\begin{array}{c}\text { Családi vállalkozás } \\
\text { Vállalkozás és/vagyy } \\
\text { szállodalánc }\end{array}$ \\
\hline C & Néhányév & Oktatás, iskolai étterem & $\begin{array}{c}\text { Turisztikai tapasztalat, } \\
\text { külföld }\end{array}$ & Oktatás \\
\hline D & Szakmai gyakorlat (3 hónap) & Szállodai HK, nemzetközi szállodalánc & Munkakeresés & Kétséges \\
\hline E & Kb. 1év & Utazási iroda, hotel recepció & Szállodai recepció & Kétséges \\
\hline F & Szakmai gyakorlat & Állami szerv, turisztikai tréningek & Munka meghiúsulása & Saját vállalkozás \\
\hline
\end{tabular}

Forrás: saját szerkesztés

A legtöbb Turizmus-menedzsment mesterszakos hallgató már elsőéves korában rendelkezik turisztikai szakmai tapasztalattal, habár a terület és a gyakorlat hossza eltérô. A legnépszerúbb munkahelyek a szállodák, de a fókuszcsoport tagjainak utazási irodai, idegenvezetôi és vendéglátós tapasztalatuk is van. A hallgatókat a szektorban szerzett szakmai tapasztalat egyelőre nem tántorította el, nagy részük a jövóben is a turizmusban kíván elhelyezkedni. Azonban a pozitív tapasztalatok mellett negatívumként a követelőző, nehezen kezelhetô vendégeket részletezték a hallgatók, mivel a szakmai tapasztalattal rendelkezők elsősorban front területen dolgoztak. A nyári terveket illetően a hallgatók elsődlegesen a turizmus területén kívánnak munkát vállalni. A csoport kisebb része már rendelkezik konkrét munkahellyel vagy ígérettel a munkahelyre vonatkozóan, de van olyan, aki épp a koronavírus-járvány okozta válság miatt nem tud a saját országában munkát vállalni, miközben Magyarországra sem tud beutazni, hogy az itteni turizmus szektorban keressen állást.

A másodéves Turizmus-menedzsment mesterszakos hallgatók mindegyike rendelkezik turisztikai szakmai tapasztalattal (2. táblázat). A munkatapasztalatok 3 hónaptól több, mint 8 évig terjednek. A turisztikai területek között a szálloda és az utazási iroda dominál, de az állami apparátusban múködő turisztikai munkahely is megtalálható. A munkákkal kapcsolatban jó és rossz tapasztalatról is beszámoltak a résztvevők, melyek később kerülnek részletezésre. A koronavírus-járvány hatására a nyári munkalehetőség vált semmissé, illetve nehezebbé vált a munkakeresés, mely érthető módon jobban aggasztja a végzősöket, mint az elsóéveseket. Van, akinek biztos munkája vagy arra vonatkozó ígérete van, de több hallgató esetében reménytelennek tûnik a helyzet. Az ő számukra fontos stratégia a tanulás, további képzéseken való rész- vétel, amit a nyitás után jól tudnak majd használni, vagy akár már most képesek belőle jövedelmet szerezni. A saját vállalkozásban dolgozó hallgató esetében a nyár mindenképpen egy fontos időszak lesz a jövedelemszerzés szempontjából. Mivel a cég tevékenysége a nyári idôszakban csúcsosodik ki, számukra a 2020-as év nem jelentett túl nagy veszteséget, míg a 2021-es évben csak bizonyos, a jelenlegi helyzetben előírt higiéniai szempontoknak nem megfeleló szolgáltatásokat nem indíthatnak. A jövóbeni tervek között arányaiban is lényegesen kevesebb a biztosan a turizmusban elhelyezkedők aránya. A turizmus iránt érdeklődők pedig inkább saját vállalkozást indítanának.

\subsection{COVID19 HATÁSA AZ ELSÖÉVES ÉS A VÉGZÖS HALLGATÓK ESETÉBEN}

Külsô tényezôként a koronavírus-járvány hatásait és az azzal kapcsolatos érintettséget vizsgáltuk a Turizmus-menedzsment mesterszakos hallgatók szakmai, illetve magánéletében. Az interjúk során megnevezett véleményeket szófelhőben jelenítettük meg, ahol az 1. ábra az elsőéves mesterszakos hallgatók által megnevezett kifejezéseket mutatja, míg a 2. ábrában a végzős hallgatók véleménye látható.

Az elsóéves mesterszakos hallgatók számára ugyanolyan sokk volt a koronavírus-járvány kitörése, mint a szektor számára. A hallgatóknál az oktatással kapcsolatos változások domináltak. Az online oktatás megjelenése, illetve megtapasztalása új kihívások elé állította az oktatásban részt vevő összes érintettet. A hallgatók mind pozitív, mind negatív értelemben említették az online oktatást, de a jelenlegi helyzetben a negatív tényezók hatásai érződtek erősebbnek. A csoport összetételéból következóen a vízumproblémák is több említést kaptak, melyek az oktatáshoz való hozzáférést 
1. ábra például a Magyarországra történő utazás kétszer

A Covid19 hatása az elsóéves mesterszakos hallgatók életére

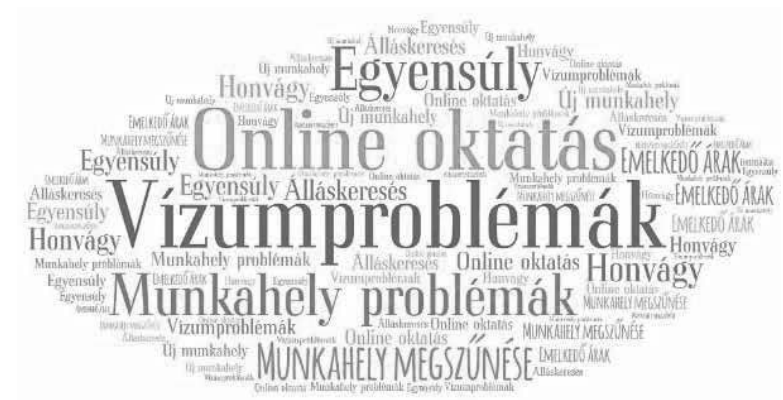

Forrás: saját szerkesztés

A Covid19 hatása a végzôs mesterszakos hallgatók életére

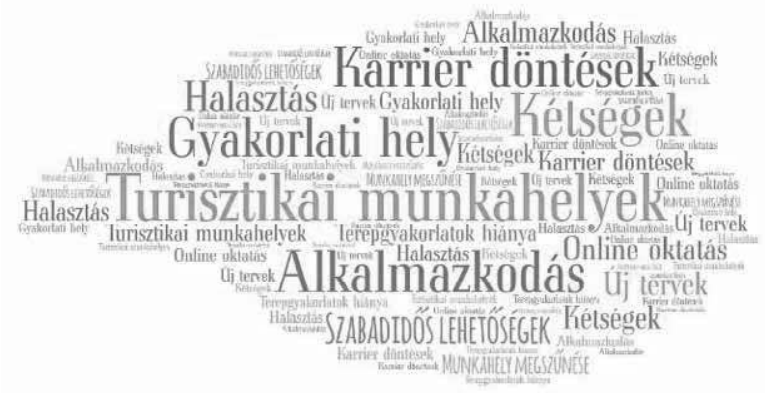

Forrás: saját szerkesztés

nehezítették a számukra. Vagy később tudták elkezdeni a tanulmányaikat, vagy nem tudták folytatni azt. Turizmus-menedzsment mesterszakos hallgatók lévén sokaknak van munkatapasztalata vagy a jelenlegi helyzet előtt, vagy az alatt vállaltak, vállalnak munkát. A globális tendenciák a mesterszakos hallgatók munkahelyeinek esetében is érezhetőek voltak. Munkahelyek szúntek meg, majd indultak újra, továbbá a munkahelyváltások vagy a munkavállalás is jellemezte ezt az időszakot a vizsgált csoport számára. A munkahelyeken tapasztalt bizonytalanság a turisztikai munkahelyek tekintetében különösen nehézzé tette a 2020/21-es tanévet. A Covid19-járvány azonban a nyugalom, a lelassulás élményét is elhozta a csoport néhány tagja számára, tehát egyensúlyt teremtett a személyes életében. Az egyensúly a csoport más tagjai számára a munka és a tanulás közti harmónia megteremtését jelentette, ami olyan kihívás, amit önként nem vállaltak volna a hallgatók, de a járványhelyzet kényszere megteremtette ennek szükségességét. A pandémia következtében növekvő árak, ami a lakosság számára is érezhetô, a beutazás költségeit még inkább érinti. Az egyik hallgató számára annyiba került, mint a járvány előtt. A nemzetközi csoport tagjai között van olyan, aki a Covid19 miatt már négy éve nem látta a családját, nem járt az otthonában, tehát a honvágy is a járványhelyzet meghatározó hatásai közé tartozik.

A végzős Turizmus-menedzsment mesterszakos hallgatók a Covid19 hatásai közül a turisztikai munkahelyeket, illetve azok helyzetét emelték ki leginkább. A járvány hatására megszúntek a turisztikai munkahelyek, a nyári munkák. A végzősök számára kifejezetten fontos a megfelelő mennyiségú gyakorlat megszerzése, amit tanulmányaik során többnyire a nyári időszakban tudnak megszerezni. Legtöbbjük számára a járvány miatt hiúsult meg a szakmai gyakorlati lehetőség 2020 nyarán, ami egyértelmúen gátolja a késóbbi, megfelelő pozícióban való elhelyezkedési lehetóségeiket. Emellett a munkahelyek megszúnése is jellemző volt erre az időszakra. A járvány előhívta az alkalmazkodás szükségességét. Adaptálódni kellett az új oktatási helyzethez, az online oktatáshoz, valamint új tervek készítését is szükségessé tette. A végzős turizmus mesterszakos hallgatók számára a karrierdöntések kifejezetten fontosak, mivel élethelyzetükból adódóan közvetlenül karrierjük kezdetén állnak. Karrierdöntésüket ma a kétségek jellemzik, a hallgatók nagy része megkérdőjelezte a jövőbeli turisztikai karrier lehetőségét. A járványnak kifejezetten negatív hatását érzik a turisztikai vállalkozások - szállodák és utazási irodák hangzottak el a fókuszcsoportokban - a munkatársakkal szembeni viselkedésben és a financiális kérdésekben. Mivel nem látják a vonzó turisztikai munkalehetôségeket, a turizmus iránt igazán elkötelezett csoporttagok inkább saját vállalkozás indításában látják a saját szerepüket a jövőben. Azonban ezeknek a vállalkozásoknak egy részét csak késóbb tudnák elindítani, amikor a járványhelyzet stabilizálódik, és a kereslet újra felélénkül. Az online oktatás említése a végzősöknél kevésbé volt jellemző, melynek oka abban is kereshető, hogy már a második évüket teljesítik online formátumban. Az online oktatás fejlődését azonban említették, hogy így is mennyire hatékonyan lehet elsajátítani a tananyagot, a terepgyakorlatok hiányát viszont negatívumként élték meg.

\subsection{A TURIZMUS JÖVÖJE A MESTERSZAKOS HALLGATÓK ÖSSZESÍTETT VÉLEMÉNYE ALAPJÁN}

Kutatásunk során kiemelt hangsúlyt fektettünk arra, hogy megismerjük a turizmus mesterszakos hallgatók turisztikai jövóképét. A válaszokat a 3. táblázatban összegeztük. 
3. táblázat

A turizmus jövőjének megítélése az elsőévesek és a végzős mesterszakos hallgatók körében

\begin{tabular}{|l|l|}
\hline \multicolumn{2}{|c|}{ Felsőbb évesek } \\
\hline \multicolumn{1}{|c|}{ Régi normál } & \multicolumn{1}{c|}{ Új normál } \\
\hline Ugyanazon elemek & Fejlödés \\
\hline Ugyanazon munkafeltételek & Alkalmazkodás \\
\hline Ugyanúgy sérülékeny marad & Munkavállalói érdekképviselet \\
\hline & Munkafeltételek javulása \\
\hline & $\begin{array}{l}\text { Bizonyos desztinációk } \\
\text { felemelkedése }\end{array}$ \\
\hline \multicolumn{2}{|c|}{ Elsóévesek } \\
\hline Régi normál & \multicolumn{1}{c|}{ Új normál } \\
\hline Tömegturizmus & Új megoldások \\
\hline & Fenntarthatóság \\
\hline & Technológiai fejlődés \\
\hline
\end{tabular}

Forrás. saját szerkesztés

A turizmus jövőjével kapcsolatban a hallgatók egy része optimista, másik részük pesszimista álláspontot képvisel. A pesszimista hallgatók elsôsorban azt hangsúlyozták, hogy a turizmus szektor nem fog változni, visszatér ugyanazokhoz a sajátosságokhoz, elvekhez, melyek a járvány előtt jellemezték. Az előző alfejezetben részletezett munkafeltételeknél is említésre került tényezők a véleményük szerint nem fognak változni, a turizmus visszatér az eredeti üzleti modellhez, és nem fejlődik a járvány okozta kihívások megválaszolása által. Külön kiemelésre került az utazási irodai szektor, mely az egyik résztvevó országában kifejezetten alacsony színvonalú és a legkevésbé kedvező munkafeltételeket nyújtja, ami véleménye szerint a késóbbiekben sem fog változni.

Azonban az optimista nézet szerint az új normál egy alkalmazkodóbb, még jobb eredményeket nyújtó turizmus lesz, ami a legjobbat próbálja kihozni a kialakult helyzetból. Emellett az új normálban, az egyik nemzetközi hallgató szerint, a munkavállalók érdekképviseletének erôsítésére lenne szükség, ami hozzájárulna a szakma jobb megbecsültségéhez és a munkafeltételek javulásához. Itt került említésre az employer branding (munkáltatói márkaépítés) hatékonyabb alkalmazása a szakmában, a dolgozók motiválása, megbecsülése és a lojalitás értékelése, amelyre már a szakirodalom áttekintése kapcsán is utaltunk (LIN et al. 2018).

Az optimista nézethez kapcsolódik, hogy bizonyos desztinációk felemelkedésére lehet számítani, ilyen az egyik résztvevó országa is. Ezeken a területeken - a tervek szerint és az eddigi jelek alapján
- erősödik a légi forgalom, nemzetközi szállodaláncok nyitnak szállodát, és egyre több diák tanul turizmussal kapcsolatos ismereteket.

Az elsőéves mesterszakos hallgatók hozzászólásaik alapján jellemzően bizakodóbbak voltak, azonban többen nehéznek ítélték a jövőben való gondolkodást, illetve a jóslást, mivel a tavaly tavaszi időszakban is a járvány végét prognosztizálták a szakemberek, amiben aztán tévedtek. A válaszok inkább az új normált mutatták attól függetlenül, hogy a konkrét kifejezés nem került említésre. Szerintük a turizmus alkalmazkodó lesz, és az új kihívásokra új megoldásokkal válaszol. Megjelent náluk a fenntarthatóság gondolata is, ami az újfajta turizmust fogja jellemezni. A régi modellból egyedül a tömegturizmust emelték ki, miszerint az utazási éhség az eddig is látogatott térségekben újra tömeget fog okozni.

\section{5. Összegzés és konklúzió}

A kutatás fontos célja, hogy a végzôs hallgatók pályaválasztását, illetve esetleges pályaelhagyását vizsgálja, és rávilágítson a turizmus szakma jövőjére a mesterszakos hallgatók szemszögéból nézve.

Elsô kutatási kérdésünkben arra kerestük a választ, hogy a turizmusban tanuló hallgatóknak milyen elvárásaik vannak a turisztikai munkavállalással kapcsolatban és mi jellemzi a munkaorientációjukat. A turisztikai munkavégzéssel kapcsolatban az elsóéves mesterszakos hallgatók véleménye sokkal bizakodóbb volt, mint a végzősöké. A megnevezett szakmai motiváló tényezők közül legtöbben az anyagi és a szakmai megbecsülést tartják fontosnak, míg a munkavégzésben a szakmai kihívásokat, a változatos feladatokat és a megfeleló munkaidő-beosztást. A válaszokból látható, hogy kiemelkedő jelentőségú a pozitív szakmai orientáció, a szakma szeretete.

Az interjúk során kirajzolódott, hogy a Covid19járvány a hallgatók életét is megnehezítette, de a nehézségek ellenére is kitartanak a turizmus mellett, és kezdeti karrierlépéseiket a turizmus területén tervezik megtenni. Ugyanakkor ahhoz, hogy ez ne változzon, a szakmának is lépéseket kell tennie, nem elég a pályakezdók elhivatottságára építeni, ha hosszabb távon is szeretnék megórizni a turisztikai munkavállalási kedvet.

Éppen ezért tervezünk egy többéves kutatást, amelyet a mostani kutatási eredmények alapoztak meg. A többéves kutatással célunk egy komplex metodika kidolgozása a karrierút két (szubjektív és objektív) oldalának mérésére, melyben a mérés végzôs hallgatókkal kezdődik, és olyan pályaelhagyókkal végzódik, akik valamilyen nem lineáris karrier mellett döntöttek. Az egyéni karrierutak 
vizsgálata során feltérképezhetjük a munka, illetve a munkahely változtatása, valamint a gyorsan változó körülmények miatt szükségessé váló adaptációs stratégiákat. A pályaelhagyás kétoldalú (már elhagyók, végzős hallgatók) vizsgálata újszerú megközelítés, illetve ezen csoportok pályaelhagyási motivációinak elemzése újdonságként egészítené ki az eddig inkább végzős diákok percepcióit tartalmazó szakirodalmat.

A mostani feltáró kutatásunk legnagyobb korlátja a kis mintanagyság volt, ugyanakkor rávilágított azokra a sarokpontokra, amelyek megalapozzák a kutatás további szakaszait, kiegészítve annak módszertani eszköztárát. A kutatás eredménye előrevetíti annak lehetőségét, hogy más képzési helyekre járó mesterszakos hallgatók véleményével egészítsük ki, bóvítsük a mintát, feltárva az esetleges kulturális és földrajzi eltéréseket. Emellett a kutatást kibóvíthetjük a munkáltatók és a szakmai szervezetek véleményének megismerésével, amely egy másik nézőpontból vizsgálja a kutatási problémát, a pályakezdők helyzetét. A kutatási eredmények gyakorlati hasznosítása több érintett szempontjából is megvalósulhat. Az elemzés során szerzett információ pedig hozzájárulhat a felsőoktatási intézmények beiskolázási mutatóinak javulásához és a piaci nehézségek jobb megismeréséhez a turisztikai szektorban. A kutatások bővítésével ajánlásokat szeretnénk megfogalmazni a döntéshozók, a szakmai szervezetek és a felsőoktatási intézmények számára, amelyekkel vonzóbbá tehető a turizmus szakma.

\section{Köszönetnyilvánítás}

A tanulmány nem jöhetett volna létre a Turizmusmenedzsment mesterszakos hallgatók közremúködése nélkül.

\section{Felhasznált irodalom}

AIGBEDO, H. (2021): The impact of COVID-19 on the hospitality industry: A supply chain resilience perspectives. International Journal of Hospitality Management. 98.

https://doi.org/10.1016/j.ijhm.2021.103012

AIREY, D. - FRONTISTIS, A. (1997): Attitudes to careers in tourism: an Anglo Greek comparison. Tourism Management. 18(3). pp. 149-158. https://doi.org/10.1016/S0261-5177(96)00116-1

AKGUNDUZ, Y. - ALKAN, C. - GÖK, Ö. (2018): Perceived organizational support, employee creativity and proactive personality: The mediating effect of meaning of work. Journal of Hospitality and Tourism Management. 34. pp. 105-114. https://doi.org/10.1016/j.jhtm.2018.01.004
ARNOUX-NICOLAS, C. -SOVET, L. - BERNAUD, J. (2017): Development and validation of the meaning of work inventory among French workers. International Journal for Educational and Vocational Guidance. 17. pp. 165-185. https://doi.org/10.1007/s10775-016-9323-0

COLLINS-KREINER, N. - RAM, Y. (2021): National tourism strategies during the Covid-19 pandemic. Annals of Tourism Research. 89. https://doi.org/10.1016/j.annals.2020.103076

FARMAKI, A. (2018): Tourism and hospitality internships: A prologue to career intentions? Journal of Hospitality, Leisure, Sport $\mathcal{E}$ Tourism Education. 23. pp. 50-58. https://doi.org/10.1016/j.jhlste.2018.06.002

FELKAI P. (2021): Hogyan utazzunk a COVID járvány után? Turizmus Bulletin. 21(1). pp. 44-48. https://doi.org/10.14267/TURBULL.2021v21n1.5

FILIMONAU, V. - DERQUI, B. - MATUTE, J. (2020): The COVID-19 pandemic and organisational commitment of senior hotel managers. International Journal of Hospitality Management. 91. https://doi.org/10.1016/j.ijhm.2020.102659

FORMADI, K. (2008): From Health to Tourism: Being mobile in the Wellness Sector. In: Kuhlmann, E. - Saks, M. (eds): Rethinking professional governance: International directions in health care. The Policy Press, Bristol. pp. 187-201.

FORMÁDI, K. - RAFFAI, CS. (2009): New Professionalism in the Event Sector and its Impact in Hungary. In: Baum, T. - Smith, K. - Lockstone, L. (eds): People and Work in Events and Conventions. A Research Perspectives. CABI Publication, London. pp. 75-92.

FOTIADIS, A. - POLYZOS, S. - HUAN, T. C. (2021): The good, the bad and the ugly on COVID-19 tourism recovery. Annals of Tourism Research. 87. https://doi.org/10.1016/j.annals.2020.103117

GETZ, D. (1994): Students' work experiences, perceptions and attitudes towards careers in hospitality and tourism: a longitudinal case study in Spey Valley, Scotland. International Journal of Hospitality Management. 13(1). pp. 25-37.

https://doi.org/10.1177/004728759403300285

GOLDTHORPE, J. H. - LOCKWOOD, D. BECHHOFER, F. - PLATT, J. (1968): The Affluent Worker: Industrial Attitudes and Behaviour. Cambridge: Cambridge University Press.

GUERRIER, Y. (1987): Hotel managers' careers and their impact on hotels in Britain. International Journal of Hospitality Management. 6(3). pp. 121130. https://doi.org/10.1016/0278-4319(89)90018-2

HARPAZ, I. - HONIG, B. - COETSIER, P. (2002): A cross-cultural longitudinal analysis of the 
meaning of work and the socialization process of career starters. Journal of World Business. 37(4). pp. 230-244. https://doi.org/10.1016/S1090-9516(02)00090-1

JOPPE, M. (2012): Migrant workers: Challenges and opportunities in addressing tourism labour shortages. Tourism management. 33(3). pp. 662-671.

https://doi.org/10.1016/J.TOURMAN.2011.07.009

JUNG, H. - YOON, H. (2016): What does work meaning to hospitality employees? The effects of meaningful work on employees' organizational commitment: The mediating role of job engagement. International Journal of Hospitality Management. 53. pp. 59-68. https://doi.org/10.1016/j.ijhm.2015.12.004

KIM, S. - JUNG, J. - WANG, K. C. (2016): Hospitality and tourism management students' study and career preferences: Comparison of three Asian regional groups. Journal of Hospitality, Leisure, Sport E Tourism Education. 19. pp. 66-84. https://doi.org/10.1016/j.jhlste.2016.05.002

LIN, M.-Y. - CHIANG, C.-F. - WU, K.-P. (2018): How Hospitality and Tourism Students Choose Careers: Influences of Employer Branding and Applicants' Customer Orientation. Journal of Hospitality \& Tourism Education. 30(4). pp. 229-240. https://doi.org/10.1080/10963758.2018.1480377

LIN, P. M. C. - AU, W. C. - LEUNG, W. T. Y. PENG, K.-L. (2020): Exploring the meaning of work within the sharing economy: A case of food-delivery workers. International Journal of Hospitality Management. 91. https://doi.org/10.1016/j.ijhm.2020.102686

LIPS-WIERSMA, M. - WRIGHT, S. (2012): Measuring the Meaning of Meaningful Work: Development and Validation of the Comprehensive Meaningful Work Scale (CMWS). Group \& Organization Management. 37(5). pp. 655-685. https://doi.org/10.1177/1059601112461578

LOCKE, E. A. (1984): Job Satisfaction. In: Gruenberg, M. - Wall, T. (eds): Social Psychology and Organizational Behavior. London: Wiley.

RAMAKRISHNANA, S. - MACAVEIU, C. (2019) Understanding aspirations in tourism students. Journal of Hospitality and Tourism Management. 39. pp. 40-48.

RASHEED, M. I. - OKUMUS, F. - WENG, Q. D. HAMEED, Z. - NAWAZ, M. S. (2020): Career adaptability and employee turnover intentions: The role of perceived career opportunities and orientation to happiness in the hospitality industry. Journal of Hospitality and Tourism Management. 44. pp. 98-107.

https://doi.org/10.1016/j.jhtm.2020.05.006
REED, K. (1997): Orientations to work: the cultural conditioning of motivation. The Australian and New Zealand Journal of Sociology. 33(3). pp. 364-386.

https://doi.org/10.1177/144078339703300306

RICHARDSON, S. (2009): Undergraduates' perceptions of tourism and hospitality as a career choice. International Journal of Hospitality Management. 28(3). pp. 382-388.

https://doi.org/10.1016/j.ijhm.2008.10.006

RICHARDSON, S. - THOMAS, N. J. (2012): Utilising Generation Y: United States Hospitality and Tourism Students' Perceptions of Careers in the Industry. Journal of Hospitality and Tourism Management. 19(1). pp. 102-114. https://doi.org/10.1017/jht.2012.12

SHARMA, G. D. - THOMAS, A. - PAUL, J. (2021): Reviving tourism industry postCOVID-19: A resilience-based framework. Tourism Management Perspectives. 37. https://doi.org/10.1016/j.tmp.2020.100786

SIGALA, M. (2020): Tourism and COVID-19: Impacts and implications for advancing and resetting industry and research. Journal of Business Research. 117. pp. 312-321.

https://doi.org/10.1016/j.jbusres.2020.06.015

UĞUR, N. G. - AKBIYIK, A. (2020): Impacts of COVID-19 on global tourism industry: A cross-regional comparison. Tourism Management Perspectives. 36.

https://doi.org/10.1016/j.tmp.2020.100744

WATSON, T. (1995): Sociology of Work and Industry. London: Routledge.

ZHANG, H. -SONG, H. - LONGW. - LIU, C. (2020): Forecasting tourism recovery amid COVID-19. Annals of Tourism Research. 87. 103149.

https://doi.org/10.1016/j.annals.2021.103149

\section{Internetes források}

KSH (2020): A turizmus és vendéglátás fontosabb adatai. https://www.ksh.hu/stadat_files/tur/ hu/tur0001.html, Letöltve: 2021. június 24.

MTÜ (2017a): Budapest vendégforgalma. https:// mtu.gov.hu/documents/prod/Budapest_ vendegforgalma_2017_3.pdf, Letöltve: 2021. június 24 .

MTÜ (2017b): Magyarország legnépszerübb települései. https://mtu.gov.hu/documents/ prod/Magyarorszag_legnepszerubb_ telepulesei_2017.pdf, Letöltve: 2021. június 24.

MTÜ (2019): A turizmus eredményei Magyarországon. https://mtu.gov.hu/cikkek/a-turizmuseredmenyei-magyarorszagon, Letöltve: 2021. június 24 . 
OECD (2020): OECD Employment Outlook 2020 - Worker security and the COVID-19 Crisis. https://www.oecd-ilibrary.org/sites/ 1686c758-en $/ 1 / 1 /$ index.html?itemId=/ content/publication/1686c758-en\&_csp_ $=$ fc80786ea6a3a7b4628d3f05b1e2e5d7\&itemIGO= oecd\&itemContentType=book, Letöltve: 2021. június 24.

TURIZMUS ONLINE (2019): Hátráltatja a turizmust a munkaeröhiány. http://turizmusonline.hu/ belfold/cikk/hatraltatja_a_turizmust_a_ munkaerohiany, Letöltve: 2021. szeptember 5.

TURIZMUS.COM (2021a): Krónikus munkaerőhiányt vizionálnak a szálloda- és vendéglátóiparban. https://turizmus.com/szallashely-vendeglatas/ kronikus-munkaerohiany-sujthatja-ajovoben-a-vendeglato-es-szallodaipart-1174030, Letöltve: 2021. augusztus 24.

UNWTO (2020): World Tourism Barometer 2020. https://www.unwto.org/world-tourismbarometer-n18-january-2020, Letöltve: 2021. június 26.

TURIZMUS.COM (2021b): A szállodák 25-30 százaléka nyithat hétvégén - interjú Baldauf Csabával. https://turizmus.com/szallashely-vendeglatas/ szallodak-nyitas-hetvegen-baldaufcsaba-1174634, Letöltve: 2021. augusztus 24. 